\title{
Community energy and equity: The distributional implications of a transition to a decentralised electricity system
}

\author{
Victoria C. A. Johnson* \\ Sustainable Consumption Institute, University of Manchester
}

Stephen Hall

School of Earth and Environment, University of Leeds

With contributions from: John Barton, Damie Emanuel-Yusuf, Noel Longhurst, Áine O'Grady, Elizabeth Robertson, Elaine Robinson, Fionnguala SherryBrennan

\begin{abstract}
This paper explores the equity implications of a transition to a decentralised energy system in the UK. We base our analysis on one of three idealised transition pathways developed by the EPSRC-funded Realising Transition Pathways (RTP) project. Each pathway is characterised by a different mix of technologies, ownership and governance of the energy transition, and stretches from 2010 to 2050. In this paper we focus on the 'Thousand Flowers' (TF) pathway, which stipulates a much greater role for civil society in the energy system. Here, civil society actors are instrumental in delivering 50 per cent of final electricity demand from decentralised, low-carbon sources by 2050 . Such a radical and systemic transition will require both institutional as well as technological change. The systemic institutional transformation necessary to support wide-spread adoption of community/decentralised energy schemes and the potential distributional impacts have, however, received limited attention to date. To address this gap, we draw on collected outputs of the RTP consortium and extant literatures on community and decentralised energy to explore potential institutional barriers and distributional impacts of the TF pathway. We argue a transition to a TF future would require significant institutional changes to UK energy governance, new municipal and community business models, and new financial and organisational structures in energy ownership. Second, widespread adoption of distributed energy sources would undermine the viability of traditional large power plants; leading to the need for new forms of state support to maintain assets at transmission level. Finally, we contend that expanded community energy provision has the potential to reproduce, or even exacerbate, existing socio-economic and spatial inequalities.
\end{abstract}

Keywords: decentralised; energy; governance; pathways; community; equity. 
p. 150. Community energy and equity: The distributional implications of a transition to a decentralised electricity system

\section{Introduction}

The future of the UK's electricity system has attracted increasing attention from a range of domestic, international, state, market and civil society interests. System transitions are framed by the 'energy trilemma': energy security fears, linked to the UK's import dependence and an ageing energy infrastructure; commitment to meeting Climate Change Act (2008) targets; and concern regarding affordability (DECC, 2011). These challenges are compounded by stagnation or falling real incomes for much of the UK population (Taylor et al., 2014) and widespread mistrust of the energy sector (Ofgem, 2014a).

The diversity of interests in UK energy policy has led to increased polarisation regarding the socio-technical configuration of the future energy system. Regardless of the pathway that is eventually navigated, significant transformations in technological systems, institutions, business strategies and user practices will need to occur (Foxon, 2011).

Mainstream future projections focus on technological mixes or cost optimisation (Barton et al., 2013a) and are advocated by incumbent actors (Geels, 2014; Smith, 2012, 2005). These models are often predicated on non-explicit assumptions about stable models of governance and the roles of familiar actors, viz. a market-led transition based on centralised generation (Bolton and Foxon, 2013; Hain et al., 2005; Mitchell, 2010). These assumptions however, represent just one possible pathway that could support a low-carbon transition. Greatly expanded distributed generation, comprising many small-scale assets connected to the local distribution networks, as opposed to step down one-way power flow from the national transmission system, is another technologically feasible pathway (Barton et al., 2013b).

This decentralised, distributed pathway is often marginalised in least cost models and current national planning (Bridge et al., 2013). While technologies may present higher system capital costs (Trutnevyte et al., under review), they also offer the opportunity for civil society to capture value from generation, distribution and supply (Capener, 2014; Cox and Johnson, 2010). Furthermore, due to the centralised structure of energy finance, markets and infrastructures, contemporary energy policy has been designed to favour large-scale generation and corporate ownership (Bolton and Foxon, 2013). This is to the detriment of building strong alternative energy movements (Breukers and Wolsink, 2007; Toke et al., 2008).

Despite an unfavourable policy environment, there is growing interest from a range of stakeholders, devolved governments, municipalities, and communities in the potential of capturing value from distributed energy systems (Core Cities, 2013; Platt et al., 2014). Motivations for stakeholder interest in decentralised generation are wide ranging including; local economic development, employment creation, community cohesion, democratic participation, environmental education and local to global environmental concerns (Hannon et al., 2013; Hargreaves et al., 2013; Seyfang et al., 2013). Year-on-year, the number of decentralised generation schemes grows (Capener, 2014; SmartestEnergy, 2014); although market penetration remains low and activity is neither coherent nor well-co-ordinated (Smith, 2012). In 2013, community energy schemes and municipally owned generation did not exceed two per cent of final demand (DECC, 2014).

Long-term visions and interrogation of the real potential of distributed generation do exist, yet these tend to focus on technological potential (e.g. Greenpeace, 2005; Veerapen and Beerepoot, 2011), specific types of ownership models, challenges facing decentralised deployment (e.g. Dodd, 2008; Willis and Willis, 2012) or are geographically limited (e.g. GLA, 2011; Sherwood and Tompt, 2013). As such, how and 
under what circumstances the 'up-scaling' of community energy might occur has remained relatively elusive. In particular, the institutional architecture (intermediary institutions and their relationships to each other) to support and coordinate a transition to a more decentralised sector has been given surprisingly little attention. This is central to the realisation of such a transition (Geels and Deuten, 2006; Hargreaves et al., 2013; Howells, 2006; Moss, 2009; Seiwald, 2014). In particular, significant gaps in understanding exist regarding the feasibility of scaling-out small-scale decentralised generation from governance, regulation, policy, and financial perspectives (Seyfang, 2009; Smith, 2007). Similarly, little attention has been paid to the distributional impacts of such a transition (Platt et al., 2014). Although scholars are beginning to examine the social impacts of community energy (Rogers et al., 2012) and drivers of participation (Hargreaves et al., 2013; Hoffman and High-Pippert, 2010), the current debate has remained silent on the wider distributional impacts driven by existing structural and spatial inequalities.

Drawing on work across the Realising Transition Pathways consortium and the extant literatures on community energy, this paper examines institutional structures more suited to delivering a distributed energy system and discusses the potential socio-economic impacts of pursuing such a future. We frame our analysis by utilising the 'Thousand Flowers' pathway; a distributed energy scenario developed as part of two major interdisciplinary research projects funded by the UK Engineering and Physical Sciences Research Council: Transition Pathways (Foxon et al., 2010) and more recently, Realising Transition Pathways (henceforth, RTP) ${ }^{1}$. The 'Thousand Flowers' pathway is discussed in more detail in Section 2.

Research by the Transition Pathways project has demonstrated that it is technically possible for 50 per cent of final UK energy demand to be generated from distributed sources by 2050 (Barton et al., 2013b), while more recent work by the RTP project has examined the technological feasibility and types of governance, ownership and control this distributed energy future might need (RTP Engine Room, forthcoming).

The paper is structured as follows. Section 2 describes the set of pathways developed by the Transition Pathways and RTP projects. Section 3 presents three systemic changes that may be required to facilitate wide scale adoption of alternative energy systems. Section 4 discusses the equity implications of such a transition. Our main conclusions are presented in Section 5.

\section{The transition pathways}

Scenario analyses are a useful tool for understanding and managing the complexity of delivering a low-carbon transition and anticipating social, environmental and economic outcomes. They continue to play a significant role in informing research, policy and practice. While the majority of scenario analyses are rich in technological detail (e.g. rates of adoption of low-carbon technologies), and economic and social constraints (e.g. additional energy system costs); they often rely heavily on exogenous emissions constraints or high-level trends. The corollary is that a deeper understanding of the non-technological dynamics of the transitions (actors, their motivations, and institutions) has often been lacking. This matters because transitions of socio-technical systems, such as the UK's electricity system, involve the co-evolution of technological systems, institutions, business strategies and user practices (Foxon et al., 2010; Hughes and Strachan, 2010; Schot and Geels, 2008; Verbong and Geels, 2012).

To address this omission, Transition Pathways and more recently RTP applied a whole systems assessment framework to develop and interrogate three idealised transition pathways for the UK energy system. A specific framing or 'logic' of different 
p. 152. Community energy and equity: The distributional implications of a transition to a decentralised electricity system

types of ownership in the energy system drives each pathway. These include: state, market and civil society (see Table 1). Each pathway is characterised by a different mix of technologies, ownership and governance of the energy transition from 2010 to 2050. The 'Central Coordination' and 'Market Rules' pathways emphasise the dominant role of state or private actors in leading the energy transition respectively. While these pathways incorporate tough challenges, they rely on leadership from hitherto familiar stakeholders in the UK energy sector. The 'Thousand Flowers' (henceforth, TF) pathway is different.

Table 1: Summary of 3 idealised pathways developed by the Realising Transition Pathways Project (Foxon et al., 2010)

\begin{tabular}{|c|c|c|c|}
\hline Pathway & $\begin{array}{l}\text { Governance } \\
\text { logic }\end{array}$ & Dominant actor & Description \\
\hline $\begin{array}{l}\text { Central } \\
\text { Coordination }\end{array}$ & State & $\begin{array}{l}\text { Central } \\
\text { government }\end{array}$ & $\begin{array}{l}\text { Central to this pathway is the role of } \\
\text { the nation state in actively } \\
\text { delivering the transition. }\end{array}$ \\
\hline Market Rules & Market & $\begin{array}{l}\text { Private sector (e.g. } \\
\text { large energy firms) }\end{array}$ & $\begin{array}{l}\text { After the creation of a broad, high- } \\
\text { level policy framework, the state } \\
\text { allows competition and private } \\
\text { companies to deliver the transition }\end{array}$ \\
\hline $\begin{array}{l}\text { Thousand } \\
\text { Flowers }\end{array}$ & Civil Society & $\begin{array}{l}\text { Civil society (e.g. } \\
\text { community and } \\
\text { environmental } \\
\text { groups) }\end{array}$ & $\begin{array}{l}\text { Energy systems should meet the } \\
\text { needs of citizens, who should } \\
\text { therefore take a leading role in the } \\
\text { decisions relating to how the energy } \\
\text { system operates. }\end{array}$ \\
\hline
\end{tabular}

Central to the achievement of the TF pathway is the proliferation of local energy schemes delivered by a 'civic energy sector', defined here as: schemes that capture values from energy generation either through co-operative, municipal, charitable, or citizen investment business models (Hall et al., 2014). The use of the signifier civic as opposed to community reflects the importance of municipalities (the local state), citizen investors, and importance of regions and geography in the shaping of the pathway.

According to the TF pathway, described in detail in Foxon et al (2010) and summarised in Table 2, by 2050 the actors in this sector come together to supply 50 per cent of final electricity demand through locally owned distributed assets. The remaining 50 per cent of electricity generation is highly efficient gas plant with carbon capture and storage (CCS), offshore wind, nuclear, and hydro connected to the national transmission grid. 
p. 153. Community energy and equity: The distributional implications of a transition to a decentralised electricity system

Table 2: Key characteristics of the Thousand Flowers pathway (Foxon, 2013)

\begin{tabular}{l|l}
\hline Key governance & $\begin{array}{l}\text { Dominance of civil society logic in which citizens take a leading role } \\
\text { in the decisions relating to how their local and national energy } \\
\text { system operates. }\end{array}$ \\
\hline Key technologies & $\begin{array}{l}\text { Onshore wind; offshore wind; renewable CHP; solar PV; imports; } \\
\text { tidal barrage; wave and tidal power. }\end{array}$ \\
\hline Key concepts & $\begin{array}{l}\text { Move to ESCo business model; technological and behavioural } \\
\text { changes lead to significant end-user demand reductions; positive } \\
\text { feedbacks lead to virtuous cycles in deployment of small-scale } \\
\text { distributed generation technologies; greater community ownership } \\
\text { of generation, including onshore wind and biomass CHP. }\end{array}$ \\
\hline Key actors & $\begin{array}{l}\text { ESCos (new entrants and diversified existing energy companies); } \\
\text { local communities; NGOs. }\end{array}$ \\
\hline patterns multi-level & $\begin{array}{l}\text { Landscape pressures (climate change and energy security) on } \\
\text { regime actors and government support for small-scale and } \\
\text { community-level initiatives leads to focus on demand reduction and } \\
\text { small-scale technologies; small-scale renewable technologies } \\
\text { emerge from niches. }\end{array}$ \\
\hline Key learning & $\begin{array}{l}\text { Learning to achieve commercial deployment of a range of } \\
\text { distributed generation technologies, with the emergence of a small } \\
\text { number of dominant designs; large energy companies diversify into } \\
\text { ESCo business models; focus on community-led renewable district } \\
\text { heating schemes reduces the expected demand for electric heating, } \\
\text { but rise in demand from electric vehicles. }\end{array}$ \\
\hline Key infrastructure \\
aspects
\end{tabular}

\section{Current technological configuration}

Traditionally, electricity has been generated by large centralised plant and transported by the high voltage transmission network to areas of high demand, distribution companies and large industrial consumers. The distribution network operators (DNOs) then transport electricity through the medium-low voltage distribution network to commercial and domestic consumers. Current grid infrastructure, built in the 1950s and 60s was, therefore, designed to function for this one-way power flow. The inherent inertia of the system (large sunk costs, long-term investments and institutional arrangements) has made it difficult to move away from this paradigm (e.g. Unruh, 2000). Today, the electricity supply industry remains relatively the same; with 90 per cent of electricity still generated by major power producers (DECC, 2014b). The generation mix remains heavily reliant on carbon intensive primary fuels, particularly coal and natural gas. In 2012, renewable generation accounted for just 11.3 per cent of total electricity generation (Ibid.).

In contrast, the TF pathway stipulates that the generation mix evolves from one dominated by large power generators providing predictable and mostly flexible electricity to a scenario with a significantly greater proportion of highly variable and less flexible generation. A new approach to balancing the grid will have to be taken, with more demand side participation and 'smarter' grid networks. 
p. 154. Community energy and equity: The distributional implications of a transition to a decentralised electricity system

\section{Current institutional arrangements}

The UK electricity system is divided into elements that constitute a competitive market (generation and supply) and regulated monopolies (transmission and distribution). Post market liberalisation, the competitive markets of generation and supply have been delivered by corporate utilities and dominated by the Big Six (Centrica (British Gas), EDF Energy, E.ON, RWE npower, ScottishPower and SSE) (Rutledge, 2012). These firms exist as a group of vertically integrated energy utilities that, together, hold a majority market share of generation and supply. Ofgem (The Office of Gas and Electricity Markets) regulates the competitive and regulated elements of the system. The transmission system is owned by National Grid and the 14 original distribution board networks are now operated by seven corporate groups (Ofgem, 2014a), five of which are owned by international firms (Cumbers et al., 2013; Pond, 2006).

In the electricity supply market, the Big Six hold a market share of 95 per cent of domestic supply and 80 per cent of commercial supply (Ofgem, 2014b). There is, however, evidence that the ecology of the supply sector is now changing. In the quarter to 31 January 2013, aggregate shares of household energy markets held by the major suppliers dropped below 95 per cent, the lowest levels in the history of the competitive market (Buckley and Moss, 2014). By the end of 2013 there were a total of 24 companies offering electricity and/or gas supply to households and 30 companies offering electricity and/or gas supply to commercial consumers (Buckley and Moss, 2014; Moss and Buckley, 2014). While market shares of the Big Six are falling overall, concerns have been raised by Ofgem as to the poor outcomes being realised by householders and SMEs (Moss and Buckley, 2014; Ofgem, 2014b).

In terms of generation ownership, Rutledge (2012) describes a 'Big Ten' which includes the Big Six alongside ESB, Drax, GDF Suez and AES. In 2012, these ten companies collectively owned 85.8 per cent of UK generation assets. The remaining 14.2 per cent is made up of 64 medium sized private companies and corporate entities. The community energy sector owns just 0.3 per cent of renewable capacity; approximately 60MW (DECC, 2014a). Comparable figures for municipal generation assets are unavailable but are unlikely to exceed one per cent (Hannon et al., 2013).

The TF pathway imagines an alternative; the proliferation of distributed energy generators, which are owned fully or in part by municipalities, communities, or smallscale investors. Recent Government discourse has recognised the role community energy can play in meeting demand (Foxon, 2013), culminating in the recent Community Energy Strategy (DECC, 2014a). The Strategy sets out Coalition Government plans for incentivising community ownership of energy generation. In the most optimistic scenario, the community energy sector could account for 3GW of installed capacity by 2020, 1.4 per cent of total electricity demand (Capener, 2014). Whilst the Strategy represents a significant step forward in propagating new forms of energy ownership, their definition of community energy limits the scope for new ownership to expand in the generation sector. For example, the definition does not include generation assets owned by institutions such as combined authorities, local authorities, town and parish councils, or social housing providers. As for the included technologies; CHP, anaerobic digestion, wave, tidal, and biomass technologies, are outside the definition. Both the institutional and technological omissions from the DECC strategy have made a substantive contribution to the TF pathway.

Evidence from other European nations demonstrates that levels of 'civic energy generation' defined in the TF pathway are possible. Proliferation to European levels of capacity, however, requires an understanding that these levels are achievable, and can be exceeded if the right mix of institutions, resources, finance and expertise can be 
p. 155. Community energy and equity: The distributional implications of a transition to a decentralised electricity system

developed at the local level. Expanding this sector would require a significant step change to local, regional and national institutional capacities and the functioning of electricity wholesale and supply markets.

Research from the RTP consortium and from the wider debate on community and local energy, has identified distinct barriers to the proliferation of distributed energy at significant scale, these are: a finance gap for community energy schemes, incompatible supply market structures, the effect on transmission level assets, and grid integration and infrastructure. This is not an exhaustive list, but does represent key barriers to expanding the sector. Below each are briefly explored before we move on to question potential equity implications.

\section{Barriers to expanding a civic energy sector}

The barriers identified here were drawn from extant work by the RTP consortium and interrogated through a series of interdisciplinary workshops with scholars and practitioners, designed to address specific questions and constraints raised by the TF pathway described above. The full output of this work, and the institutional architecture the research group found to be compatible with the TF pathway, is presented in RTP Engine Room (forthcoming). Here, we draw on this work, published works of the RTP consortium and broader community energy literature to frame the four barriers identified above.

\section{Financing community energy}

There is a 'finance' gap identified for community energy schemes below $£ 20 \mathrm{~m}$ (DECC, 2014a; Nolden, 2013). This is, in part, due to the structure of the UK banking industry which is as centralised as the energy system, and mismatched to the needs of civic actors (Hall et al., 2014). As such, local financial structures will be required to underpin the expansion of the civic energy sector. In Germany there has been a long tradition of civic ownership of generation assets, including municipal ownership (Schönberger, 2013; Toke et al., 2008). Regular access to finance from co-operative, state-owned, and local banks has been shown to play a central role in facilitating this sector (Berlin Landesbank, 2011; Bolinger, 2001; Bremer Landesbank, 2014). For example, by 2010, energy assets with an element of civic ownership made up 40-50 per cent of Germany's total renewable energy capacity (Buchan, 2012; Nolden, 2013), and much of this was made up of local developer partnerships with local share issues.

For the UK to achieve an energy transition similar to the TF pathway, a contingent replication of such models would be necessary with substantial growth in the mechanisms of citizen and mutual finance that underpin the European civic energy sector. There are signs of an emerging smaller scale citizen finance sector in the UK. Abundance Generation ${ }^{2}$ offers debentures for small scale investors, while Pure Leapfrog aims to build portfolios of projects in order to reduce financial risk through aggregation. ${ }^{3}$ The County of Hampshire is in the process of establishing a community bank tasked with delivering a low-carbon economy, and they explicitly cite the German banking model as key to supporting renewable energies (Future Solent, 2014). For now however this finance gap remains real for the UK civic energy sector. 
p. 156. Community energy and equity: The distributional implications of a transition to a decentralised electricity system

\section{Addressing the supply market structure}

The expansion of community energy generation in the UK depends on community energy generators finding a route to market for the electricity they produce. An expansion of small scale generation schemes would need to be matched with expansion of civic business models in supplier relationships (Platt et al, 2014; RTP Engine Room, forthcoming). Large generators are able to bear the transaction costs inherent in trading on the wholesale market; for smaller generators however, these transaction costs are often too high relative to the power produced. As such, smaller scale independent generators tend to secure 'Power Purchase Agreements' (PPAs) with major suppliers. As small producers with intermittent generation do not offer an attractive prospect to major suppliers, they have often struggled to secure bankable PPAs (DECC, 2014c; DTI, 2007).

RTP researchers have argued that in order to proliferate distributed energy in the UK, there is a need for new, local supplier business models that have significant involvement from municipal actors (Bolton and Foxon, 2013; Hall et al., 2014). Further, in order to avoid a situation where these new suppliers are reliant on a "units of energy sold' business model, thus dis-incentivising demand reduction (Hannon et al., 2013; Roelich et al., 2015), these municipal models should be based on an Energy Supply Company (ESCo) model (Hannon et al., 2013; Foxon, 2013; Bolton and Foxon, 2014). Thus RTP researchers have emphasised that municipal actors and the ESCo model, play a significant role in the TF pathway (Hannon et al., 2013; Foxon, 2013). RTP Engine Room (forthcoming) expand upon these findings.

From outside the RTP consortium there are further calls for municipal participation to underpin community generators (Hoffman et al., 2013; Julian, 2014; Platt et al., 2014); calls which are being answered. For example, the Core Cities network (a consortium of the ten largest British cities outside London) has signalled intent to establish electricity supply companies with the express aim of underpinning community generation (Core Cities, 2013). This builds on a very small, but emergent sector of municipal supply in the UK (Hall et al., 2014; Platt et al., 2014). Municipalities have been proposed as key actors in the TF pathway and other distributed energy visions, as they have the potential to significantly support and become part of a civic energy transition.

\section{Ensuring security of supply, reproducing transmission level generation}

It is beyond the scope of this paper to offer a detailed description of the wholesale energy market (see Mitchell, 2014; Sioshansi, 2013). However it is important to note the functioning of the wholesale electricity market can be subject to a 'merit order' effect (Pöyry, 2010; Zachmann, 2007). Here, the cheapest way to satisfy electricity demand is by using plant with the lowest marginal cost of generation. Wind and solar for example have zero fuel cost and so are incentivised to sell whatever power they produce; they are at the top of the 'merit order' because they can typically accept lower wholesale prices due to both subsidy and low marginal production costs. The next type of plant utilised is thermal plant with low marginal costs such as coal and nuclear. As demand increases during peak times (cold, dark days) the least efficient (in terms of marginal cost, the most expensive) fossil fuel thermal plant is used. The 'merit order' effect is difficult to observe in the UK due to wholesale trading arrangements and low penetration of renewable energies relative to European counterparts. What is important to note here, however, is the inverse relationship between renewable generation and use of the peaking plant. 
The need to renew much of the ageing thermal capacity in the UK has led to 'Capacity Payments' through the Electricity Market Reform. These provide more certainty for investors building and maintaining peaking plant such as flexible gas assets (DECC, 2012; Redpoint, 2010). Analyses by Channell et al. (2013) and Mitchell (2014), however, question the viability of traditional utility business models in financing large thermal plant if distributed renewables eat into their traditional roles as providers of peaking capacity and base load. Similarly for the TF pathway, RTP researchers have shown that significant increases in intermittent generation and distributed energy provision would mean transmission level assets would run with lower capacity factors than is currently the case (Barton et al., 2013b).

A substantial expansion of community scale renewable energy then, challenges the business model of flexible gas generation, often used to cover demand peaks. This is undesirable for the expansion of community energy as any increase in intermittent generation at the local level would need to be backed up by flexible generation elsewhere on the system, which in the TF pathway is provided by highly efficient gas plant with carbon capture and storage (Foxon et al., 2010). Channell et al., 2013 show how this leads to the need for these flexible assets to be subsidised either by the state or by consumers in some form of capacity payment. As such an expansion of community renewables to the scale of the TF scenario may require new transmission level plant to be heavily subsidised in order to remain a feasible investment. We argue this could potentially heighten public discourse on the renationalisation of elements of the energy sector (see also Section 4.2).

\section{Delivering Smarter Grids}

New infrastructures and ICT are required in local and regional electricity distribution networks to enable best use of distributed energy resources. RTP researchers have demonstrated the governance and regulation of the UK's distribution system militates against making the necessary infrastructural investments (Bolton and Foxon, 2014; Pudjianto et al., 2013). Further, RTP researchers have proposed that greater municipal and civic engagement could lead to new business models and institutional arrangements for cost sharing and planning in the physical distribution networks (Hall and Foxon, 2014).

This has the potential to accelerate the deployment of smart grid solutions in the UK, but may require new governance approaches. In practice, communities from beyond the UK are beginning to bring distribution grids back into municipal ownership in order to pursue environmental, self-governance and economic development goals (Fei and Rinehart, 2014; Hall et al., 2014). Under the TF pathway there would be a need for significant smart grid infrastructure. Given the governance logic of the pathway, these municipal and civil society approaches to smart grid ownership and proliferation may provide new ways to fund smart grid investment in the UK.

\section{Summary}

There is a significant need for scholars of community, citizen and municipal energy futures to pay attention to the systemic effects of distributed energy on the energy system. This short section has highlighted four systemic issues which are being interrogated across the RTP consortium. These are financing community generation, the route to market and role of municipal suppliers, the effect of distributed energy on transmission asset investment and new business models for smart grid infrastructures. 
p. 158. Community energy and equity: The distributional implications of a transition to a decentralised electricity system

\section{Distributing power? Three equity challenges in civic energy}

The question of how to overcome the systemic barriers identified above is a fertile ground for further research. As in much of the wider debate around community energy, however, the cumulative effects of resolving these issues on spatial and societal equity have, so far, received little attention. Whilst discussion of the equitable distribution of benefits within particular project groups is reasonably well established (Park, 2012; Seyfang et al., 2013; Walker and Devine-Wright, 2008) the cumulative, systemic equity implications of addressing these issues across spatial and socio-economic groups are less well understood. We frame this analysis by posing three 'equity challenges' for research, and practice, in civic energy systems: finance and accessibility; fair provision of balancing capacity; and ensuring spatial equity.

\section{Finance and accessibility}

The financial structures used to underpin community energy schemes in the UK can take many forms (Walker and Devine-Wright, 2008). What has been under-researched to date is the accessibility of these financial structures for all socio-economic groups within a particular community. In the German case cited above (also, Hall et al., 2014; Nolden, 2013) there are several financial structures available to all income groups to take a stake in local energy projects. The co-operative approach has been utilised in several UK community energy schemes, but participation depends on individuals having the financial capacity to invest.

Against the backdrop of the recent financial crisis of 2008, the UK has seen rising levels of inequality and poverty due to high levels of unemployment, wage stagnation, the rising cost of living, and less secure housing tenure (Belfield et al., 2014; Dorling, 2014). As such, the availability of citizen capital for community energy in all communities cannot be taken as a given. While greater public involvement can reduce the likelihood of local opposition (NIMBYism) to renewable energy schemes, such as onshore wind farms, greater public involvement is not always possible where benefits are disputed or seen as inequitably distributed (Walker et al., 2007). Similar issues have been raised concerning the coalition government's 'Big Society' project, which foregrounds local solutions such as community energy but may do so at the expense of socio-economic equity (e.g. Kisby, 2010; North, 2011; Park, 2012).

We argue it is naïve to assume that everyone can participate in community energy since many schemes are dependent on members having sufficient income and resources (e.g. time) to invest. Park (2012) describes social capital as a key equity concern for community energy. Basic financial capital and the mechanisms by which it might be deployed, however, are an equally immediate concern. As Walker and Cass, (2007: 467) conclude, "Just as there are inequalities in access to energy consumption, we should equally expect there to be inequalities in access to energy citizenship and the benefits this brings."

There is a clear need for scholars of sustainable energy futures to be much more explicit about the geographies of class and socio-economic reproduction inherent in the business models and financial structures being used to capitalise UK community energy. The question that needs to be addressed is: if community energy is delivering values locally, who within each locality is capturing these values? Further, how can the design of community energy financial structures and business models of community energy enhance inclusivity by, for example, offering opportunities for entry to all income groups? A leading example is Brixton Energy. In 2013, the south-east London renewable energy co-operative used crowd-funding to finance a solar array in the 
p. 159. Community energy and equity: The distributional implications of a transition to a decentralised electricity system

Roupell Park estate in Brixton; offering residents of the estate a lower minimum investment threshold (£50) compared to outside investors (£250). ${ }^{4}$

\section{Fair provision of balancing capacity}

Entirely under-researched to date has been the effect of community energy on balancing capacity and peaking plant on the wider energy system. Under the RTP TF pathway, and indeed any scenario of greatly expanded distributed generation, the economic viability of larger thermal plant is of key concern. This is likely to lead to some form of expanded subsidy, capacity payment-based or otherwise. Just as the distribution of value flowing from the community-owned assets is important, so is the distribution of value derived from such a subsidy.

Almost 75 per cent of UK generation capacity is owned by large utilities not based in the UK, of which almost 20 per cent is owned by non-UK state-owned companies (Rutledge, 2012, see Table 3). Whilst international ownership of critical infrastructure may not faze neo-classical economists, it may concern the general public, and public acceptability is important for system legitimacy. Though capacity auctions for peaking plant are currently underway, and largely unchallenged, it is unclear as to the public acceptability of leveraging further subsidy from consumer bills to build new nuclear and other thermal capacity, especially where this capacity is to be owned by non-UK governments or companies and this plant may lie idle much of the time. There is the option of reintroducing state ownership to provide these assets, yet the UK government does not own significant shares in any companies likely to invest in transmission level generation in the near future. Cumbers et al (2013) and Rutledge (2012) reiterate this point and highlight the flows of bills and subsidies do not remain within the UK, '...foreign corporations are benefitting twice [...] from current UK energy policy, first from revenue extraction and second from UK government subsidy.' (Cumbers et al., 2013: 3)

Table 3: Profile of Non-UK State-Owned Companies which currently own 20 per cent of UK generation assets (Rutledge, 2012)

\begin{tabular}{lll}
\hline Firm & Country & \% state equity \\
\hline Vattenfall & Sweden & 100 \\
Statkraft & Norway & 100 \\
ESB & Eire & 100 \\
Masdar & Abu Dhabi, UAE & 100 \\
EDF & France & 85 \\
DONG & Denmark & 76 \\
Statoil & Norway & 67 \\
\hline
\end{tabular}

A key question for the equity impacts of distributed energy futures, community owned or otherwise, is the flow and capture of value in the provision of the balancing plant necessary for security of supply under a distributed energy future led by intermittent renewables. This may be a crucial future issue for distributed energy, as the legitimacy of capacity payments and subsidisation of international firms is already finding its way into the popular consciousness (Macalister, 2014; Macalister and McQue, 2014; Wright, 2013). 
p. 160. Community energy and equity: The distributional implications of a transition to a decentralised electricity system

\section{Ensuring spatial equity}

The new roles for municipalities and civil society proposed in Section 3 suggest a deepening of multi-level energy governance, with an increased role for civil society and the state as governance is devolved to regional, municipal and community actors and new relationships are forged across a range of spatial scales. This is particularly relevant to the electricity supply market and smart grid infrastructure. It is suggested this could lead to a rebalancing of power and agency from state and market actors to civil society. Evidence from the coalition government's 'Big Society' project illustrates however, that if civil society is expected to take on new responsibilities, this needs to be matched with devolution of power and resources and a strong local state (Stott, 2011). It is unlikely that in practice increased civil society responsibility and the degree of subsidiarity would necessarily be redistributive or emerge unchallenged (e.g. Geels, 2014).

Subsidiarity is bound up with the coalition government's Localism agenda, which was to be the main approach to economic recovery from the $2007 / 8$ financial crisis. Localism has attracted criticism however, as a cover for retrenchment of the local state, as a mechanism for deficit reduction and as a cover for small statism (Lowndes and Pratchett, 2011; Taylor-Gooby and Stoker, 2011). Localism in the UK presages diverging institutional capacities across municipalities; Clarke and Cochrane (2013) describe the coalition's Localism agenda as 'spatial liberalism' in which the consequences of localities' actions are not mediated by any state safety net. In the US, local autonomy and spatial liberalism are far more ingrained. Scholars who have investigated the effect of spatial liberalism of sustainability programmes conclude municipal fiscal capacity is a key enabling factor and that the uneven localisation of climate action across metropolitan regions can be as much about ability to pay, as willingness to play' (Dierwechter and Wessells, 2013: 1382).

Conversely, research addressing socio-technical transitions at the sub-national scale highlight the importance of spatial and temporal heterogeneity within and between regions. For example, cities and regions will experience the challenges of socio-technical transitions differently, while their historical context, capacity, existing infrastructures, institutions and relationships across a range of spatial scales mean their response to pressures will be variable (Coutard and Rutherford, 2010; Hodson and Marvin, 2011). This variance in 'agency' means that, 'some actors or spaces [are] able to move more extensively or quicker than others. This inequality is the combined result of inclusion and exclusion (in choices, priorities, resources...) and diverging interests and capabilities, both of which may be linked to respective levels of influence and authority' (Coutard and Rutherford, 2010: 723). With increased physical, economic and relational interdependence implied by the TF scenario, would regional or subregional inequalities be reproduced should one region or municipality race ahead, increasingly capturing energy value from surrounding areas?

These concerns mirror a wider concern with the ways in which contemporary infrastructures are being delivered for the purposes of capturing private values by municipalities speculating on future growth (Cerny, 1997; Davidson and Ward, 2014). Here infrastructure networks are becoming expressions and enablers of the neoliberal city which favour the construction of 'premium and secessionary networked infrastructures' which 'marginalise less powerful users and spaces' (Graham and Marvin, 2001: 385).

The challenge for scholars of community energy is to engage with the mechanisms which provide the physical and institutional route to market for civic energy schemes. A much deeper understanding of the ways in which divergent municipal capacity 
p. 161. Community energy and equity: The distributional implications of a transition to a decentralised electricity system

constrains or enables distributed energy schemes, and what the effects of this are on geographical equity (such as access to alternative energy futures) is needed.

\section{Conclusion}

In this paper we have discussed four systemic institutional changes which may be necessary to support a distributed energy system. This is informed by the rationale that any serious effort to develop a decentralised energy system will inevitably require a different set of institutional arrangements to that which supports centralised energy production. As such, we have argued that moving to a distributed system would involve new roles of municipalities, communities, and citizens within the energy system, as well as new business models at distribution and supply level. With strong and stable financial, regulatory and institutional support, the 'civic energy sector' and its new role as investor, developer, generator, supplier and consumer could have the potential to capture a range of social, environmental and economic benefits across the value chain.

We have also argued, however, that without critical and long-term engagement, decentralisation of power could reproduce a range of existing socio-economic inequalities. In particular, we identify a significant gap in how equity is understood in decentralised energy systems, proposing three challenges for researchers of alternative energy systems: finance and accessibility; fair provision of balancing capacity; and ensuring spatial equity.

While the growth of community energy schemes in the UK is currently viewed as overwhelmingly positive in terms of sustainability discourses, the socio-economic as well as environmental dimension of sustainability remains an important arena for critical engagement. As it stands there is nothing stopping a well-resourced, wellmeaning middle class, in areas with healthy municipal finances, from capturing much of the value offered by community energy schemes. This may deliver values from the energy system to local communities, but would do nothing to rebut critiques of neoliberal environmental governance (for example, Agyeman et al., 2003), thus undermining the potential wide-ranging societal benefits that an alternative decentralised energy future could bring and wider societal support for such a transition.

\section{Notes}

1 http://www.realisingtransitionpathways.org.uk/

2 https://www.abundancegeneration.com/

3 http://www.pureleapfrog.org

4 https://brixtonenergy.co.uk/invest/

\section{Acknowledgements}

This paper builds on research carried out under the 'Realising Transition Pathways: Whole Systems Analysis for a UK More Electric Low Carbon Energy Future' Consortium Project funded by the UK Engineering and Physical Sciences Research Council (EPSRC) [under Grant EP/K005316/1]. However, the views expressed here are those of the authors alone, and do not necessarily reflect the views of the collaborators or the policies of the funding body. 
p. 162. Community energy and equity: The distributional implications of a transition to a decentralised electricity system

* Correspondence address: Dr Victoria C A Johnson, Sustainable Consumption Institute, University of Manchester, 188 Waterloo Place, Oxford Road, M13 9PL. Email: victoria.johnson-2@manchester.ac.uk

\section{References}

Agyeman, J., Bullard, R.D. and Evans, B. (2003) Just Sustainabilities: Development in an Unequal World. MIT Press.

Barton, J., Davis, L., Dooley, B., Foxon, T.J., Galloway, S., Hammond, G.P., O’Grady, Á., Robertson, E. and Thompson, M. (2013a) Transition pathways for a UK low carbon electricity system: Comparing scenarios and technology implications (Working Paper). Bath: Realising Transition Pathways, University of Bath.

Barton, J., Huang, S., Infield, D., Leach, M., Ogunkunle, D., Torriti, J. and Thomson, M. (2013b) The evolution of electricity demand and the role for demand side participation, in buildings and transport. Energy Policy, Special Section: Transition Pathways to a Low Carbon Economy, 52, 85-102. doi:10.1016/j.enpol.2012.08.040.

Belfield, C., Cribb, J., Hood, A. and Joyce, R. (2014) Living Standards, Poverty and Inequality in the UK: 2014. London: Institute for Fiscal Studies.

Berlin Landesbank (2011) ECA-covered financing of renewable energy projects. International Division, Export Finance. http://www.dena.de/fileadmin/user_upload/Veranstaltungen/2011/Vortraege_B EF_EE/06.04._12.20_Presentation_Lehniger_ECA_covered_financing.pdf

Bolinger, M. (2001) Community Wind Power Ownership Schemes in Europe and their Relevance to the United States | Electricity Markets and Policy. California: Lawrence Berkeley National Laboratory, Environmental Energy Technologies Division, Berkeley.

Bolton, R. and Foxon, T.J. (2013) Urban infrastructure dynamics: market regulation and the shaping of district energy in UK cities. Environ. Plan. A, 45, 2194-2211. doi:10.1068/a45575.

Bolton, R. and Foxon, T.J. (2014) Infrastructure transformation as a socio-technical process - Implications for the governance of energy distribution networks in the UK. Technol. Technological Forecasting and Social Change, 90, B, 538-550. DOI: 10.1016/j.techfore.2014.02.017.

Bremer Landesbank (2014) Renewable energy: The right financing partner at your side [WWW Document]. URL http://brmlbde-en.f-i-ts.info/corporatecustomers/renewable-energies/ (Accessed: 12.5.14).

Breukers, S. and Wolsink, M. (2007) Wind power implementation in changing institutional landscapes: An international comparison. Energy Policy, 35, 2737 2750. DOI:10.1016/j.enpol.2006.12.004.

Bridge, G., Bouzarovski, S., Bradshaw, M. and Eyre, N. (2013) Geographies of energy transition: Space, place and the low-carbon economy. Energy Policy, 53, 331340. DOI:10.1016/j.enpol.2012.10.066.

Buchan, D. (2012) The Energiewende - Germany's gamble. Oxford: Oxford Institute for Energy Studies, University of Oxford.

Buckley, R. and Moss, A. (2014) Competition in British Household Energy Supply Markets: An Independent Assessment. Norwich: Cornwall Energy.

Capener, P. (2014) Community Renewable Electricity Generation: Potential Sector Growth to 2020 - Methodology, Detailed Assumptions and Summary of Results. London: Department of Energy and Climate Change.

Cerny, P.G. (1997) Paradoxes of the Competition State: The Dynamics of Political Globalization. Government and Opposition, 32, 2, 251-274. DOI:10.1111/j.1477-7053.1997.tb00161.x 
p. 163. Community energy and equity: The distributional implications of a transition to a decentralised electricity system

Channell, J., Jansen, H., Syme, A., Savvantidou, S., Morse, E.L. and Yuen, A. (2013) Energy Darwinism: The Evolution of the Energy Industry. Clti GOS: Global Perspectives \& Solutions, Citigroup.

Clarke, N. and Cochrane, A. (2013) Geographies and politics of localism: The localism of the United Kingdom's coalition government. Political Geography, 34, 10-23. DOI:10.1016/j.polgeo.2013.03.003.

Core Cities (2013) Core Cities Growth Prospectus Policies Step 6: Power Up the Cities. Manchester: Core Cities.

Coutard, O. and Rutherford, J. (2010) Energy transition and city-region planning: understanding the spatial politics of systemic change. Technology Analysis and Strategic Management, 22, 711-727. DOI:10.1080/09537325.2010.496284.

Cox, E. and Johnson, V.C.A. (2010) Decarbonizing Local Economies: A New Low Carbon, High Well-being Model of Local Economic Development, In: Peters, M., Fudge, S., Jackson, T. (Eds.) Low Carbon Communities: Imaginative Approaches to Combating Climate Change Locally. Cheltenham: Edward Elgar Publishing, pp. 123-136.

Cumbers, A., Danson, M., Whittam, G., Morgan, G. and Callagan, G. (2013) Repossesing the future: A common weal strategy for community and democratic ownership of Scotland's energy resources. South Lanarkshire: The Jimmy Reid Foundation, Biggar.

Davidson, M. and Ward, K. (2014) "Picking up the pieces": austerity urbanism, California and fiscal crisis. Cambridge Journal of Regions, Economy and Society, 7, 81-97. DOI:10.1093/cjres/rst030.

Department of Energy and Climate Change [DECC] (2011) The Carbon Plan: Delivering our Low Carbon Future. London: DECC.

Department of Energy and Climate Change [DECC] (2012) Electricity Market Reform: policy overview. London: DECC.

Department of Energy and Climate Change [DECC] (2014a) Community Energy Strategy: Full Report. London: DECC.

Department of Energy and Climate Change [DECC] (2014b) Digest of United Kingdom energy statistics (DUKES) 2014. London: DECC.

Department of Energy and Climate Change [DECC] (2014c) Supporting Independent Renewable Investment: Offtaker of Last Resort - Consultation Document. London: DECC.

Department of Trade and Industry [DTI] (2007) Meeting the Energy Challenge: A White Paper on Energy. London: DTI.

Dierwechter, Y. and Wessells, A.T. (2013) The Uneven Localisation of Climate Action in Metropolitan Seattle. Urban Studies, 50, 1368-1385 DOI:10.1177/0042098013480969.

Dodd, N. (2008) Community Energy: Urban Planning for a Low Carbon Future. London: Town and Country Planning Association and Combined Heat and Power Association.

Dorling, D. (2014) All That Is Solid: How the Great Housing Disaster Defines Our Times, and What We Can Do About It. London: Allen Lane.

Fei, C. and Rinehart, I. (2014) Taking Back the Grid: Municipalization Efforts in Hamburg, Germany and Boulder, Colorado. Washington D.C: Heinrich Böll Foundation.

Foxon, T.J. (2011) A coevolutionary framework for analysing a transition to a sustainable low carbon economy. Ecological Economics, 70, 12, 2258-2267. DOI:10.1016/j.ecolecon.2011.07.014.

Foxon, T.J. (2013) Transition pathways for a UK low carbon electricity future. Energy Policy, Special Section: Transition Pathways to a Low Carbon Economy, 52, 10 24. DOI:10.1016/j.enpol.2012.04.001. 
p. 164. Community energy and equity: The distributional implications of a transition to a decentralised electricity system

Foxon, T.J., Hammond, G.P. and Pearson, P.J.G. (2010) Developing transition pathways for a low carbon electricity system in the UK. Technological Forecasting and Social Change, Issue includes a Special Section on "Infrastructures and Transitions" 77, 8, 1203-1213. DOI:10.1016/j.techfore.2010.04.002.

Geels, F. and Deuten, J.J. (2006) Local and global dynamics in technological development: a socio-cognitive perspective on knowledge flows and lessons from reinforced concrete. Science and Public Policy, 33, 4, 265-275. DOI: 10.3152/147154306781778984.

Geels, F.W. (2014) Regime Resistance against Low-Carbon Transitions: Introducing Politics and Power into the Multi-Level Perspective. Theory, Culture \& Society, 0263276414531627. DOI:10.1177/0263276414531627.

Goulsdon, A., Kerr, N., Topi, C., Dawkins, E., Kuylenstierna, J. and Pearce, R. (2012) The Economics of Low Carbon Cities: A Mini-Stern Review for the Leeds City Region. Leeds: Centre for Low Carbon Futures, University of Leeds.

Graham, S. and Marvin, S. (2001) Splintering Urbanism: Networked Infrastructures, Technological Mobilities and the Urban Condition. Psychology Press.

Greater London Authority [GLA] (2011) Decentralised energy capacity study. Phase 2 Deployment potential. London: Greater London Authority.

Greenpeace (2005) Decentralising Power: An Energy Revolution for the 21st Century. London: Greenpeace UK.

Hain, J.J., Ault, G.W., Galloway, S.J., Cruden, A. and McDonald, J.R. (2005) Additional renewable energy growth through small-scale community orientated energy policies. Energy Policy, 33, 1199-1212. DOI:10.1016/j.enpol.2003.11.017.

Hall, S., Foxon, T. and Bolton, R. (2014) The New Civic Energy Sector: implications for ownership, governance and financing of low carbon energy infrastructure. Presented at the BIEE 10th Academic Conference, St John's College, Oxford.

Hall, S. and Foxon, T.J. (2014) Values in the Smart Grid: the co-evolving political economy of smart distribution. Energy Policy, 74, 600-609.

Hannon, M.J., Foxon, T.J. and Gale, W.F. (2013) The co-evolutionary relationship between Energy Service Companies and the UK energy system: Implications for a low-carbon transition. Energy Policy, 61, 1031-1045. DOI:10.1016/j.enpol.2013.06.009.

Hargreaves, T., Hielscher, S., Seyfang, G. and Smith, A. (2013) Grassroots innovations in community energy: The role of intermediaries in niche development. Global Environmental Change, 23, 5, 868-880. doi:10.1016/j.gloenvcha.2013.02.008.

Hodson, M. and Marvin, S. (2011) Can cities shape socio-technical transitions and how would we know if they were? In: Harriet Bulkeley, Vanesa Castán Broto, Mike Hodson, Simon Marvin (Eds.) Cities and Low Carbon Transitions. Taylor and Francis, Hoboken, pp. 54-70.

Hoffman, S.M., Fudge, S., Pawlisch, L., High-Pippert, A., Peters, M. and Haskard, J. (2013) Public Values and Community Energy: Lessons from the US and UK. Sustainability, 5, 4, 1747-1763. DOI: 10.3390/su5041747.

Hoffman, S.M. and High-Pippert, A. (2010) From private lives to collective action: Recruitment and participation incentives for a community energy program. Energy Policy, Special Section: Carbon Reduction at Community Scale, 38, 12, 7567 7574. DOI:10.1016/j.enpol.2009.06.054.

Howells, J. (2006) Intermediation and the role of intermediaries in innovation. Research Policy, 35, 715-728. D0I:10.1016/j.respol.2006.03.005.

Hughes, N. and Strachan, N. (2010) Methodological review of UK and international low carbon scenarios. Energy Policy, The socio-economic transition towards a hydrogen economy - findings from European research, with regular papers, 38, 6056-6065. DOI:10.1016/j.enpol.2010.05.061.

Julian, C. (2014) Creating Local Energy Economies Lessons from Germany. London: Respublica. 
p. 165. Community energy and equity: The distributional implications of a transition to a decentralised electricity system

Kisby, B. (2010) The Big Society: Power to the People? The Political Quarterly, 81, 4, 484-491. DOI:10.1111/j.1467-923X.2010.02133.x.

Lovins, A.B. (1977) Soft energy paths: toward a durable peace. Cambridge, Mass: Ballinger Publishing Company.

Lowndes, V. and Pratchett, L. (2011) Local Governance under the Coalition Government: Austerity, Localism and the "Big Society." Local Government Studies, 38, 1, 21-40. DOI:10.1080/03003930.2011.642949.

Macalister, T. (2014) EU approves Hinkley Point nuclear power station as costs raise by $£ 8 b n$. The Guardian.

Macalister, T. and McQue, K. (2014) EDF in line for $£ 800 m$ windfall from subsidy scheme to keep lights on. The Guardian.

Mitchell, C. (2010) The Political Economy of Sustainable Energy, 2nd ed. Basingstoke: Palgrave Macmillan.

Mitchell, C. (2014) Governance and disruptive energy systems. Presented at the International Workshop on Incumbent-Challenger Interactions in Energy Transitions, Stuttgart, p. 33.

Moss, A. and Buckley, R. (2014) Competition in British Business Energy Supply Markets: An Independent Assessment for Energy UK. Norwich: Cornwall Energy.

Moss, T. (2009) Intermediaries and the governance of socio-technical networks in transition. Environment and Planning $A, 41,6,1480-1495$. DOI: 10.1068/a4116.

Nolden, C. (2013) Governing community energy-Feed-in tariffs and the development of community wind energy schemes in the United Kingdom and Germany. Energy Policy, 63, 543-552. doi:10.1016/j.enpol.2013.08.050.

North, P. (2011) Geographies and utopias of Cameron's Big Society. Social \& Cultural Geography, 12, 8, 817-827. DOI:10.1080/14649365.2011.618889.

Office of Gas and Electricity Markets [Ofgem] (2014a) State of the Market Assessment. London: Ofgem.

Office of Gas and Electricity Markets [Ofgem] (2014b) The retail market review: Implementation of simplier tariff choices and clear information. London: Ofgem.

Park, J.J. (2012) Fostering community energy and equal opportunities between communities. Local Environment, 17, 4, 387-408. DOI:10.1080/13549839.2012.678321.

Platt, R., Straw, W., Aldridge, J. and Williams, J. (2014) City Energy: A New Powerhouse for Britain. London: Institute for Public Policy Research.

Pond, R. (2006) Liberalisation, privatisation and regulation in the UK electricity sector. London: Working Lives Research Institute.

Pöyry (2010) Wind Energy and Electricity Prices: Exploring the "merit order effect." Brussels, Belgium: European Wind Energy Assocation.

Pudjianto, D., Djapic, P., Aunedi, M., Gan, C.K., Strbac, G., Huang, S. and Infield, D. (2013) Smart control for minimizing distribution network reinforcement cost due to electrification. Energy Policy, 52, 76-84.

Realising Transition Pathways Engine Room [RTP EngineRoom] (forthcoming) Distributing power: A transition to a civic energy future. Bath: Realising Transition Pathways Research Consortium, University of Bath.

Redpoint (2010) Electricity market reform, Analysis of Policy Options. Redpoint in association with Trilemma.

Roelich, K., Knoeri, C., Steinberger, J.K., Varga, L., Butler, D., Gupta, R., Harrison, G., Martin, C. and Purnell, P. (2015) Towards resource-efficient and serviceorientated integrated infrastructure operation. Technological Forecasting and Social Change, in press.

Rogers, J.C., Simmons, E.A., Convery, I. and Weatherall, A. (2012) Social impacts of community renewable energy projects: findings from a woodfuel case study. Energy Policy, 42, 239-247. DOI:10.1016/j.enpol.2011.11.081. 
p. 166. Community energy and equity: The distributional implications of a transition to a decentralised electricity system

Rutledge, I. (2012) Who owns the UK electrcity generating industry and does it matter? Chesterfield: Sheffield Energy Resources Information Services.

Schönberger, P. (2013) Municipalities as Key Actors of German Renewable Energy Governence: An Analysis of Opportunities, Obstacles adn Multi-Level Influences (No. 186), Wuppertal Papers. Wuppertal, Germany: Wuppertal Institute.

Schot, J. and Geels, F.W. (2008) Strategic niche management and sustainable innovation journeys: theory, findings, research agenda, and policy. Technology Analysis and Strategic Management, 20, 5, 537-554. DOI:10.1080/09537320802292651.

Seiwald, M. (2014) The (up) scaling of renewable energy technologies: Experiences from the Austrian biomass district heating nice. Moravian Geographical Reports, 22, 2, 44-54.

Seyfang, G. (2009) The New Economics of Sustainable Consumption: Seeds of Change. Basingstoke: Palgrave Macmillan.

Seyfang, G., Park, J.J. and Smith, A. (2013) A thousand flowers blooming? An examination of community energy in the UK. Energy Policy, 61, 977-989. DOI:10.1016/j.enpol.2013.06.030.

Sherwood, N. and Tompt, J. (2013) TEEconomy: Establishing the Potential of a Transition Enterprise Economy - Opportunities to Grow our Local Renewable Energy Economy. Herefordshire: Reconomy.

Sioshansi, F.P. (2013) Evolution of Global Electricity Markets: New Paradigms, New Challenges, New Approaches. Amsterdam, Boston: Academic Press.

SmartestEnergy (2014) Energy Entrepreneurs Report, 2014. London: SmartestEnergy.

Smith, A. (2005) The Alternative Technology Movement: An Analysis of its Framing and Negotiation of Technology Development. Human Ecology Review, 12, 106-119.

Smith, A. (2007) Translating Sustainabilities between Green Niches and SocioTechnical Regimes. Technology Analysis \& Strategic Management, 19, 4, 427 450.

Smith, A. (2012) Civil Society in Sustainable Energy Transitions, In: Verbong, G., Loorbach, D. (Eds.) Governing the Energy Transition: Reality, Illusion or Necessity? Abingdon, Oxfordshire: Routledge Ltd, pp. 180-202.

Stott, M. (2011) The Big Society Challenge. Thetford: Keystone Development Trust Publications.

Taylor, C., Jowett, A. and Hardie, M. (2014) An Examination of Falling Real Wages, 2010-2-13. Newport, Wales: Office for National Statistics.

Taylor-Gooby, P. and Stoker, G. (2011) The Coalition Programme: A New Vision for Britain or Politics as Usual? The Political Quarterly, 82, 1, 4-15. doi:10.1111/j.1467-923X.2011.02169.x

Toke, D., Breukers, S. and Wolsink, M. (2008) Wind power deployment outcomes: How can we account for the differences? Renewable and Sustainable Energy Reviews, 12, 4, 1129-1147. doi:10.1016/j.rser.2006.10.021

Trutnevyte, E., Strachan, N., Dodds, P., Pudjianto, D. and Strbac, G. (under review) Synergies and trade-offs between governance and costs: Low carbon electricity system transitions under market, government and civil society logics. Energy Policy.

Unruh, G.C. (2000) Understanding carbon lock-in. Energy Policy, 28, 817-830. DOI: 10.1016/S0301-4215(00)00070-7.

Veerapen, J. and Beerepoot, M. (2011) Co-generation and Renewables: Soutions for a Low-Carbon Energy Future. Paris, France: International Energy Agency.

Verbong, G. and Geels, F.W. (2012) Future Electricity Systems: Visions, Scenarios and Transition Pathways, In: Verbong, G., Loorbach, D. (Eds.) Governing the Energy Transition: Reality, Illusion or Necessity? Abingdon, Oxfordshire: Routledge Ltd, pp. 203-219. 
p. 167. Community energy and equity: The distributional implications of a transition to a decentralised electricity system

Walker, G. and Cass, N. (2007) Carbon reduction, "the public" and renewable energy: engaging with socio-technical configurations. Area, 39, 4, 458-469. DOI:10.1111/j.1475-4762.2007.00772.x.

Walker, G. and Devine-Wright, P. (2008) Community renewable energy: What should it mean? Energy Policy, 36, 497-500. DOl:10.1016/j.enpol.2007.10.019.

Walker, G., Hunter, S., Devine-Wright, P., Evans, B. and Fay, H. (2007) Harnessing Community Energies: Explaining and Evaluating Community-Based Localism in Renewable Energy Policy in the UK. Global Environmental Politics, 7, 2, 64-82. DOI:10.1162/glep.2007.7.2.64.

Willis, R. and Willis, J. (2012) Co-operative renewable energy in the UK: A guide to this growing sector. Manchester: Co-operatives UK and The Co-operative.

Wright, O. (2013) Consumers to pay "dirty" coal power subsidies for years [WWW Document]. The Independent. URL http://www.independent.co.uk/news/uk/home-news/consumers-to-pay-dirtycoal-power-subsidies-for-years-8724925.html (Accessed: 12.2.14).

Zachmann, G. (2007) A markov switching model of the merit order to compare British and German price formation (Discussion Paper No. 714). German Institute for Economic Research. 